\title{
Lung cancer and the immune system-current controversies and future opportunities
}

The interaction between cancer and the immune system has been recognized for close to a century (1). That the immune system may be engaged to achieve an enhanced anti-tumour immune response has long been suggested by the abscopal effect, where treatment at one site results in effects (tumour regression) at disease sites not subjected to treatment. This has most commonly been reported following stereotactic ablative radiotherapy (SABR), but until recently was a rarely observed phenomenon (2).

The advent of immune checkpoint inhibitor (ICI) therapy has placed the cancer-immune interaction at front of mindthrough therapeutic manipulation of the immune response, striking clinical responses have been observed in numerous malignancies, including non-small cell lung cancer (NSCLC). In metastatic (stage IV) NSCLC, where 5-year survival with conventional therapy was just $2 \%$, among selected patients, therapy with ICIs has achieved 5 -year survival of up to $30 \%$ (3). Astonishingly, a significant minority of responders maintain long-lasting disease control (4), raising the prospect of potential cure of a previously terminal condition. Consequently, the role of ICI in metastatic (5) and locally advanced (6) NSCLC is now well established.

With the recognition that the immune system may be recruited in the fight against lung cancer there is now more impetus than ever to extent the promise of ICI to a greater proportion of patients with lung cancer, and to examine what other components of the immune system may be recruited to the fight to improve outcomes in both NSCLC and small cell lung cancer (SCLC). This series of Transl Lung Cancer Res will evaluate current clinical evidence in the still-evolving understanding of the role of ICI in oncogene addicted NSCLC, and the potential pulmonary toxicity associated with ICI $(7,8)$. Biomarkers predicting response to ICI are known, though assessment of these (in particular tumour mutational burden) remains inconsistent. Current and novel approaches to ICI biomarker assessment in NSCLC are explored in a further clinicallyfocused review (9).

Lung cancer remains the leading cause of cancer-related death worldwide, due significantly to the large proportion of patients presenting with metastatic disease at diagnosis. Broadening the efficacy of ICI to a greater proportion of these patients may dramatically improve outcomes in NSCLC. Extending the promise of ICI through therapeutic harnessing of the abscopal response is the focus of reviews examining the potential for combination of ICI and tumour ablation $(10,11)$, and this series includes a brief report (12) demonstrating the potential of thermal tumour ablation (13) to impact the programmed death pathways.

Much remains unknown about the immune-cancer interaction. Even lymphocytes, the target of ICI, remain a work in progress and two reviews will discuss specific subsets of lymphocytes and their role in cancer control $(14,15)$. Finally, having been able to co-opt lymphocytes successfully into the therapeutic armamentarium, researchers are examining, will increasing enthusiasm and success, the potential to influence other key component cells within the immune system, including neutrophils and natural killer cells $(16,17)$, as part of novel therapeutic strategies in lung cancer management.

For many years, lung cancer treatments remained unchanged, and what minimal improvements in treatment outcomes were achieved were largely due to improved staging techniques (the Will Rogers phenomenon). The ability to overcome immunosuppressive signals from tumours through ICI has been transformative in the care of patients with metastatic NSCLC. The intent of this series within Trans Lung Cancer Res is to, having definitively established the enormous influence of the immune system on tumour progression and clinical outcomes, extend the benefit of immunotherapies to a greater proportion of patients with this historically dismal diagnosis.

We hope this series will spark further interest and investigation in harnessing all aspects of the immune system to achieve greater gains in clinical outcomes for our patients with lung cancer of all types and stages.

\section{Acknowledgments}

Funding: None. 


\section{Footnote}

Provenance and Peer Review: This article was commissioned by the editorial office, Translational Lung Cancer Research for the series "Lung cancer and the immune system". The article did not undergo external peer review.

Conflicts of Interest: The author has completed the ICMJE uniform disclosure form (available at http://dx.doi.org/10.21037/ tlcr-21-434). The series "Lung cancer and the immune system" was commissioned by the editorial office without any funding or sponsorship. DPS served as the unpaid Guest Editor of the series and serves as an unpaid editorial board member of Translational Lung Cancer Research from Sep 2019 to Sep 2021. The author has no other conflicts of interest to declare.

Ethical Statement: The author is accountable for all aspects of the work in ensuring that questions related to the accuracy or integrity of any part of the work are appropriately investigated and resolved.

Open Access Statement: This is an Open Access article distributed in accordance with the Creative Commons AttributionNonCommercial-NoDerivs 4.0 International License (CC BY-NC-ND 4.0), which permits the non-commercial replication and distribution of the article with the strict proviso that no changes or edits are made and the original work is properly cited (including links to both the formal publication through the relevant DOI and the license). See: https://creativecommons.org/licenses/by-nc$\mathrm{nd} / 4.0 \%$.

\section{References}

1. Murphy JB, Nakahara W. The lymphocyte in natural and induced resistance to transplanted cancer: v. histological study of the lymphoid tissue of mice with induced immunity to transplanted cancer. J Exp Med 1920;31:1-10.

2. Reynders K, Illidge T, Siva S, et al. The abscopal effect of local radiotherapy: using immunotherapy to make a rare event clinically relevant. Cancer Treat Rev 2015;41:503-10.

3. Remon J, Passiglia F, Ahn MJ, et al. Immune Checkpoint Inhibitors in Thoracic Malignancies: Review of the Existing Evidence by an IASLC Expert Panel and Recommendations. J Thorac Oncol 2020;15:914-47. Erratum in: J Thorac Oncol. 2020 Aug 7:S1556-0864(20)30586-4. doi: 10.1016/j.jtho.2020.07.006. Online ahead of print.

4. Gettinger S, Horn L, Jackman D, et al. Five-Year Follow-Up of Nivolumab in Previously Treated Advanced Non-Small-Cell Lung Cancer: Results From the CA209-003 Study. J Clin Oncol 2018;36:1675-84.

5. Gandhi L, Rodríguez-Abreu D, Gadgeel S, et al. Pembrolizumab plus Chemotherapy in Metastatic Non-Small-Cell Lung Cancer. N Engl J Med 2018;378:2078-92.

6. Faivre-Finn C, Vicente D, Kurata T, et al. Four-Year Survival With Durvalumab After Chemoradiotherapy in Stage III NSCLC-an Update From the PACIFIC Trial. J Thorac Oncol 2021;16:860-7.

7. McLean L, Leal JL, Solomon BJ, et al. Immunotherapy in oncogene addicted non-small cell lung cancer. Transl Lung Cancer Res 2021;10:2736-51.

8. Miller AR, Manser R. The knowns \& unknowns of pulmonary toxicity following immune checkpoint inhibitor therapies: a narrative review. Transl Lung Cancer Res 2021;10:2752-65.

9. Bozinovski S, Vannitamby A, Rangamuwa K, et al. Integrating endobronchial ultrasound bronchoscopy with molecular testing of immunotherapy biomarkers in non-small cell lung cancer. Transl Lung Cancer Res 2021;10:2779- 87.

10. Akanda ZZ, Neeson PJ, John T, et al. A narrative review of combined stereotactic ablative radiotherapy and immunotherapy in metastatic non-small cell lung cancer. Transl Lung Cancer Res 2021;10:2766-78.

11. Rangamuwa K, Leong T, Weeden C, et al. Thermal ablation in non-small cell lung cancer: a review of treatment modalities and the evidence for combination with immune checkpoint inhibitors. Transl Lung Cancer Res 2021;10:2842-57.

12. Rangamuwa K, Leong T, Bozinovski S, et al. Increase in tumour PD-L1 expression in non-small cell lung cancer following bronchoscopic thermal vapour ablation. Transl Lung Cancer Res 2021;10:2858-64.

13. Steinfort DP, Christie M, Antippa P, et al. Bronchoscopic Thermal Vapour Ablation for Localized Cancer Lesions of the Lung: A Clinical Feasibility Treat-and-Resect Study. Respiration 2021;100:432-42. 
14. Marceaux C, Weeden CE, Gordon CL, et al. Holding our breath: the promise of tissueresident memory T cells in lung cancer. Transl Cancer Res 2021;10:2819-29.

15. Leong TL, Bryant VL. B cells in lung cancer—not just a bystander cell: a literature review. Transl Lung Cancer Res 2021;10:2830-41.

16. Hess JB, Sutherland KD, Best SA. Exploring natural killer cell immunology as a therapeutic strategy in lung cancer. Transl Lung Cancer Res 2021;10:2788-805.

17. Aloe C, Wang H, Vlahos R, et al. Emerging and multifaceted role of neutrophils in lung cancer. Transl Lung Cancer Res 2021;10:2806-18.

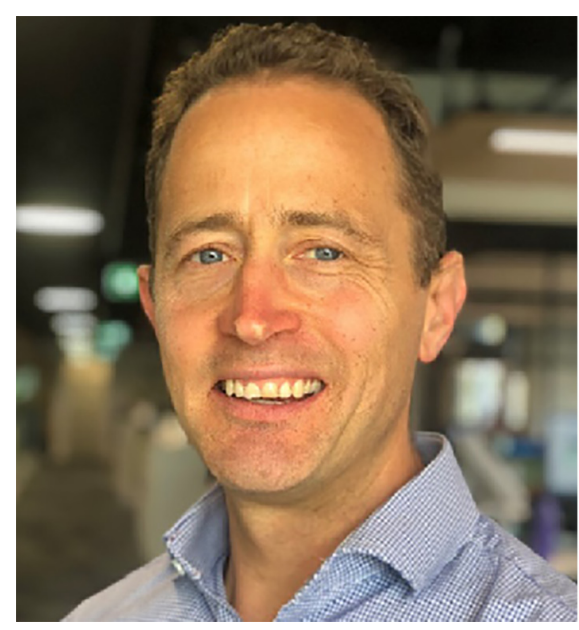

Daniel P. Steinfort

Daniel P. Steinfort ${ }^{1,2}$

${ }^{1}$ Department Respiratory Medicine, Royal Melbourne Hospital, Parkville, Australia;

${ }^{2}$ Department of Medicine, Faculty of Medicine, Dentistry \& Health Sciences, University of Melbourne, Parkville, Australia.

(Email: daniel.steinfort@mb.org.au)

Submitted May 24, 2021. Accepted for publication Jun 15, 2021. doi: $10.21037 /$ tlcr-21-434

View this article at: http://dx.doi.org/10.21037/tlcr-21-434

Cite this article as: Steinfort DP. Lung cancer and the immune system-current controversies and future opportunities. Transl Lung Cancer Res 2021;10(6):2733-2735. doi: $10.21037 /$ tlcr-21-434 